\title{
33. SEDIMENTS AND INTERSTITIAL WATER AT SITES 582 AND 584, THE NANKAI TROUGH AND THE JAPAN TRENCH LANDWARD SLOPE ${ }^{1}$
}

\author{
Hodaka Kawahata, Marine Geological Department, Geological Survey of Japan \\ and \\ Kantaro Fujioka and Toshio Ishizuka, Ocean Research Institute, University of Tokyo ${ }^{2}$
}

\begin{abstract}
Two trenches off Japan were explored during DSDP Leg 87. One is the Nankai Trough and the other is the Japan Trench; Site 582 is located on the floor of the former and Site 584 is situated on the deep-sea terrace of the latter. Cores from Site 582 and 584 consist mainly of hemipelagic sediments and diatomaceous silts and mudstone, respectively. In this report we analyze the chemistry of the interstitial water and sediments, as well as the sediment mineralogy.

Sulfate reduction is accompanied by the production of secondary pyrite, which is rich in the sediment at both sites. Dissolved $\mathrm{Ca}$ concentration is relatively low and changes only slightly at both sites, probably because of the formation of carbonate with high alkalinity. Concentrations of dissolved $\mathrm{Mg}$ decrease with depth at Site 584 . The dissolved $\mathrm{Mg}$ depletion probably results from the formation of $\mathrm{Mg}$-rich carbonate and/or ion exchange and reaction between interstitial water and clay minerals. Higher $\mathrm{Si} / \mathrm{Al}$ values are due to biogenic opal in the sediments and roughly correlate with higher values of interstitial water $\mathrm{SiO}_{2}$. Increases in dissolved $\mathrm{Li}$ concentrations may be related to its release from clay minerals, to advection that results from dewatering, and/or to fluid transport.
\end{abstract}

\section{INTRODUCTION}

The chemical composition of interstitial waters of marine sediments may be modified by many processes, particularly diagenetic reactions and diffusive and advective transport of dissolved constituents. The qualitative and quantitative estimation of the above-mentioned processes is difficult because of the complexity and variation of the reactants, the multitude of possible reactions, and the scatter of sediment physical properties data. Only Perry and others (1976) and Lawrence and others (1975) clarified the relation between interstitial water and sediments with respect to $\mathrm{Mg}, \mathrm{Ca}$, and oxygen isotope by means of the precise analysis of both phases. In addition, a few studies have been done on samples from active margins, where sediment accumulation rates are very high and many faults and fissures exist (Moore and Gieskes, 1980).

DSDP Leg 87 offered an opportunity to study the diagenesis of terrigenous sediments along an active margin. This report centers on the interstitial water chemistry of Sites 582 and 584 (Fig. 1) and incorporates information regarding sediment chemistry and mineralogy.

\section{SAMPLING AND ANALYTICAL PROCEDURES}

\section{Sampling}

Samples of interstitial water were collected at all of the Leg 87 sites by standard shipboard squeezing techniques, and several samples were collected by means of the IPOD in-hole sampler, a device that collects both water for chemical analysis in a stainless tubular coil and water for gas analysis in a connected copper coil.

\footnotetext{
${ }^{1}$ Kagami, H., Karig, D. E., Coulbourn, W. T., et al., Init. Repts. DSDP, 87: Washing ton (U.S. Govt. Printing Office).

2 Addresses: (Kawahata) Marine Geological Department, Geological Survey of Japan 1. 1-3 Higashi Yatabe, Tsukuba, Ibaraki 305, Japan; (Fujioka and Ishizuka) Ocean Research Institute, University of Tokyo, Minamidai, 1-15-1, Nakanoku, Tokyo 164, Japan.
}

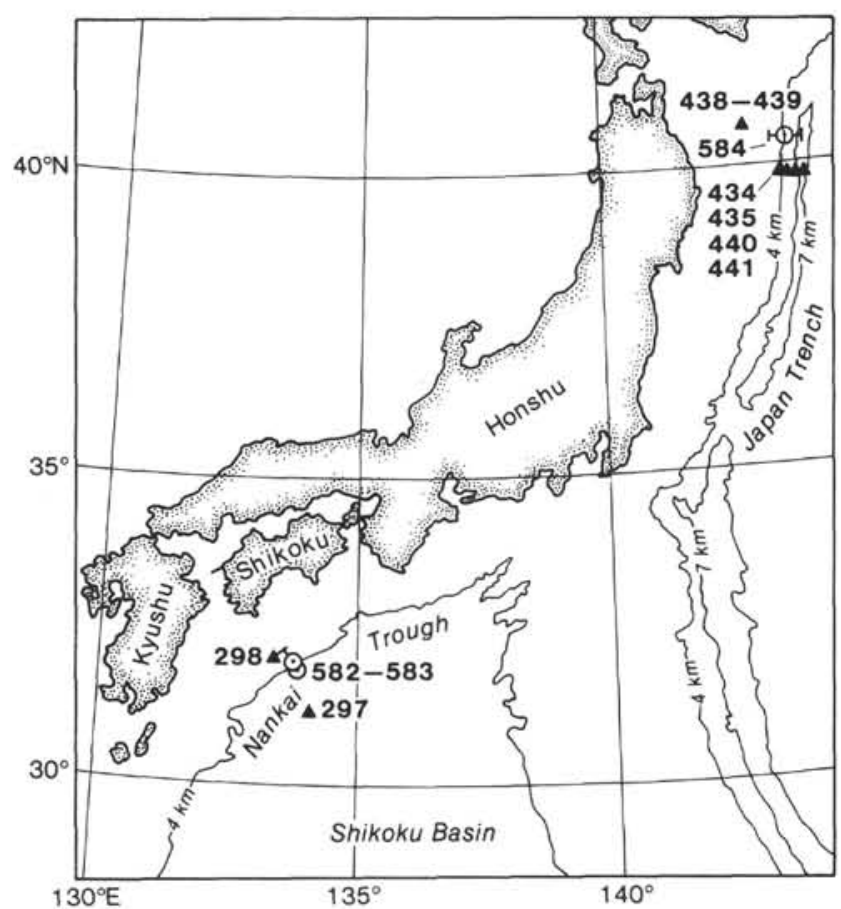

Figure 1. Location of DSDP Sites 582, 583, and 584, as well as location of earlier, related DSDP sites.

\section{Analysis of Interstitial Water}

Interstitial waters were obtained from the drilled hole(s) and analyzed on board for $\mathrm{pH}$, alkalinity, chlorinity, and salinity. On the basis of concentrations obtained by these shipboard analyses, we decided to carry out more complicated studies on samples obtained at Sites 582 and 584 .

The concentrations of $\mathrm{Li}, \mathrm{Na}, \mathrm{K}, \mathrm{Ca}$, and $\mathrm{Mg}$ were measured by a Hitachi 170-50A type atomic absorption spectrometer. All solutions were adjusted to $4000 \mathrm{ppm} \mathrm{LaCl}$ solution to prevent interference by co-existing elements. The $\mathrm{Na}$ concentration was calculated from charge balances. 
The colorimetric method was employed to test for silica (Matsui, 1963). Ammonium molybdate is added to the sample solution, resulting in the production of silicomolybdic acid. The color of this solution is yellow. Next, the reducing agent is added at regular intervals until molybdenum-blue appears. The concentration of silica is determined by measuring the absorbance of $800-\mu \mathrm{m}$ wave-length light by this blue color. The Hitachi 101 spectrophotometer was used for measurements of absorbance.

Sulfate analyses were carried out using a titration technique.

\section{Analysis of Sediments}

Bulk chemistry. The sediment samples used for chemical and mineralogic analysis are the same sediment plugs squeezed on board for interstitial water extraction. One method of analysis employs a IonCoupled Plasma (ICP) Emission Spectroscope (Javrel-Ash model 975) located at Tsukuba University. In this analysis, the JB-1, JB-2, JA-1, and JG-1 (JGS standard rocks) and the G-2, AGV-1, and BCR-1 (USGS standard rocks) served as standards. In ICP analysis, $100 \mathrm{mg}$ of sample powder is dissolved with $10 \mathrm{ml}$ of fluoric acid and $5 \mathrm{ml}$ of sulphuric acid. The solution is diluted with nitric acid and double distilled water to make a total volume of exactly $100 \mathrm{ml}$. The relative accuracy of this method is approximately $5 \%$ for each element (Notsu, 1980).

In order to normalize the variability for the nonbiogenic sediments (removing biogenic carbonate or opal), values of $\mathrm{Mg}, \mathrm{K}, \mathrm{Ca}, \mathrm{Na}$, and $\mathrm{Zn}$ are commonly reported as the atomic ratios $\mathrm{Mg} / \mathrm{Al}, \mathrm{K} / \mathrm{Al}$, and so forth. In addition $\mathrm{Al}$ should be the least mobile major element involved in any alteration or diagenetic processes.

Mineral identification. X-ray diffraction was used to identify the minerals existing in the starting materials and in the reaction products. We used the Rigaku Denshi diffractometer and $\mathrm{CuK} \alpha$ radiation.

Identification of clay minerals. Clay minerals in remnant sediments were concentrated by decantation in distilled water and centrifuged. These clay minerals were identified by X-ray diffraction patterns before and after treatment by ethylene-glycol.

\section{GENERAL CHARACTERISTICS OF SITES 582 AND 584}

Site 582 is located on the floor of the Nankai Trough about $2 \mathrm{~km}$ south of the deformation front (Fig. 1). The sediments are dark olive gray and gray turbidites and hemipelagic clays and silts (Fig. 2). Coarse sand turbidites decrease in frequency with sub-bottom depth. Trench turbidites include volcanic glass, lithic fragments, heavy minerals, red chert, well-preserved mixtures of shallow and deep benthic foraminifers, and both marine and nonmarine diatom assemblages. Site 582 is characterized by extremely high rates of accumulation during the Quaternary caused by the large input of continental-derived sediment. Biostratigraphic and paleomagnetic data suggest reduction of rates from near $900 \mathrm{~m} / \mathrm{Ma}$ before 0.4 Ma ago or earlier to less than $300 \mathrm{~m} / \mathrm{Ma}$ after $0.4 \mathrm{Ma}$ (Leg 87 Scientific Party, 1983; Karig et al., 1983).

Both the turbidites and the hemipelagic sediments of the axial deposits have an organic carbon content from 0.5 to $0.7 \%$, decreasing to less than $0.5 \%$ in the hemipelagites beneath. Hydrocarbon gases (mainly methane with very minor $\mathrm{CO}_{2}, \mathrm{C}_{2}, \mathrm{C}_{3}$, and $\mathrm{i}-\mathrm{C}_{4}$, as well as traces of $\mathrm{H}_{2} \mathrm{~S}$, isopentane, and neopentane) are present throughout the section as gas pockets. No solid gas hydrate was encountered (site chapters, Sites 582 and 584, this volume).

Site 584 is situated on the deep-sea terrace of the trench slope (Fig. 1) where $954 \mathrm{~m}$ of the sedimentary section were penetrated. The oldest sediment cored was middle Miocene. Four lithostratigraphic units are recognized (site chapter, Site 584, this volume). The uppermost $4 \mathrm{~m}$ at Hole 584 is Pleistocene sediment ( 0 to $4 \mathrm{~m}$ sub-bottom depth). A second lithologic unit (4 to $231 \mathrm{~m}$ sub-bottom depth) is lower Pliocene diatomaceous mud and mudstone. A third lithologic unit (231 to $537 \mathrm{~m}$ sub-bottom depth) is also a diatomaceous mudstone, but is distinguished by fine sand and silt beds, seaward-dipping strata, and markedly higher induration than in the overlying sediments. The Pliocene/Miocene boundary occurs within that unit, near $564 \mathrm{~m}$ sub-bottom depth, but no lithologic contrast marks the boundary. A bioturbated mudstone with a much-reduced diatom content constitutes Unit 4 (Fig. 2). Rates of sediment accumulation were estimated based on selected datum levels and are highest ( 200 to $700 \mathrm{~m} / \mathrm{Ma}$ ) for the early Pliocene and latest Miocene, a 7-Ma time span (Leg 87 Scientific Party, 1983; Karig et al., 1983).

\section{SITE 582 RESULTS FOR INTERSTITIAL WATER AND SEDIMENT CHEMISTRY AND MINERALOGY}

\section{Pore-Water Chemistry}

Salinity, $\mathrm{pH}$, and chlorinity are nearly constant with respect to sub-bottom depth at this site (Table 1). Alkalinity reaches a maximum of $45 \mathrm{meq} / \mathrm{l}$ at $200 \mathrm{~m}$ sub-bottom then remains virtually constant at about 25 mmoles/ 1 beneath 280 sub-bottom depth (Fig. 3A).

The $\mathrm{SO}_{4}$ concentration decreases to 5 mmoles/ 1 within the upper 100 to $200 \mathrm{~m}$, increases to about $25 \mathrm{mmoles} / 1$ to a total depth of $670 \mathrm{~m}$ (Fig. 3B).

The $\mathrm{Mg}$ concentration decreases to $42 \mathrm{mmoles} / \mathrm{l}$ within the upper $50 \mathrm{~m}$ of sediments, remains constant to $200 \mathrm{~m}$, then decreases to a total depth of $690 \mathrm{~m}$ (Fig. 3B).

The dissolved $\mathrm{Ca}$ is constant at $5 \mathrm{mmoles} / \mathrm{l}$, a concentration of about half that of bottom seawater (Fig. 3C).

The $\mathrm{K}$ concentration remains fairly constant throughout the section (Fig. 3C).

Dissolved Sr shows only a slight peak around $200 \mathrm{~m}$ sub-bottom and increases below $400 \mathrm{~m}$ sub-bottom (Fig. 3D).

Dissolved Li concentration increases slightly between the seafloor and $550 \mathrm{~m}$ sub-bottom in Lithologic Unit 1 and then increases rapidly below that depth in Unit 2 (Fig. 3E).

The $\mathrm{SiO}_{2}$ concentration is nearly constant throughout at about 0.6 mmoles/l (Fig. 3F).

\section{Sediment Chemistry}

The bulk chemistry of the remnant sediment samples from Sites 582 and 584 is presented in Table 2. At Site 582 , the atomic ratios for $\mathrm{Si} / \mathrm{Al}, \mathrm{Mg} / \mathrm{Al}, \mathrm{Na} / \mathrm{Al}, \mathrm{K} / \mathrm{Al}$, and $\mathrm{Li} / \mathrm{Al}$ remain low and fairly constant (Fig. 4). The $\mathrm{Ca} / \mathrm{Al}$ and $\mathrm{Sr} / \mathrm{Al}$ ratios are scattered but decrease with depth (Fig. 4C, D), and, conversely, the $\mathrm{Zn} / \mathrm{Al}$ ratio increases with depth by nearly a factor of 2 (Fig. 4H).

\section{Sediment Mineralogy}

Smear-slide estimates for Site 582 indicate that quartz and feldspar concentrations decrease gradually with depth as clay concentrations gradually increase (Fig. 5). Clay minerals present include kaolinite, illite, and smectite. Pyrite is found in all the sections at concentrations of $2-9 \%$ 

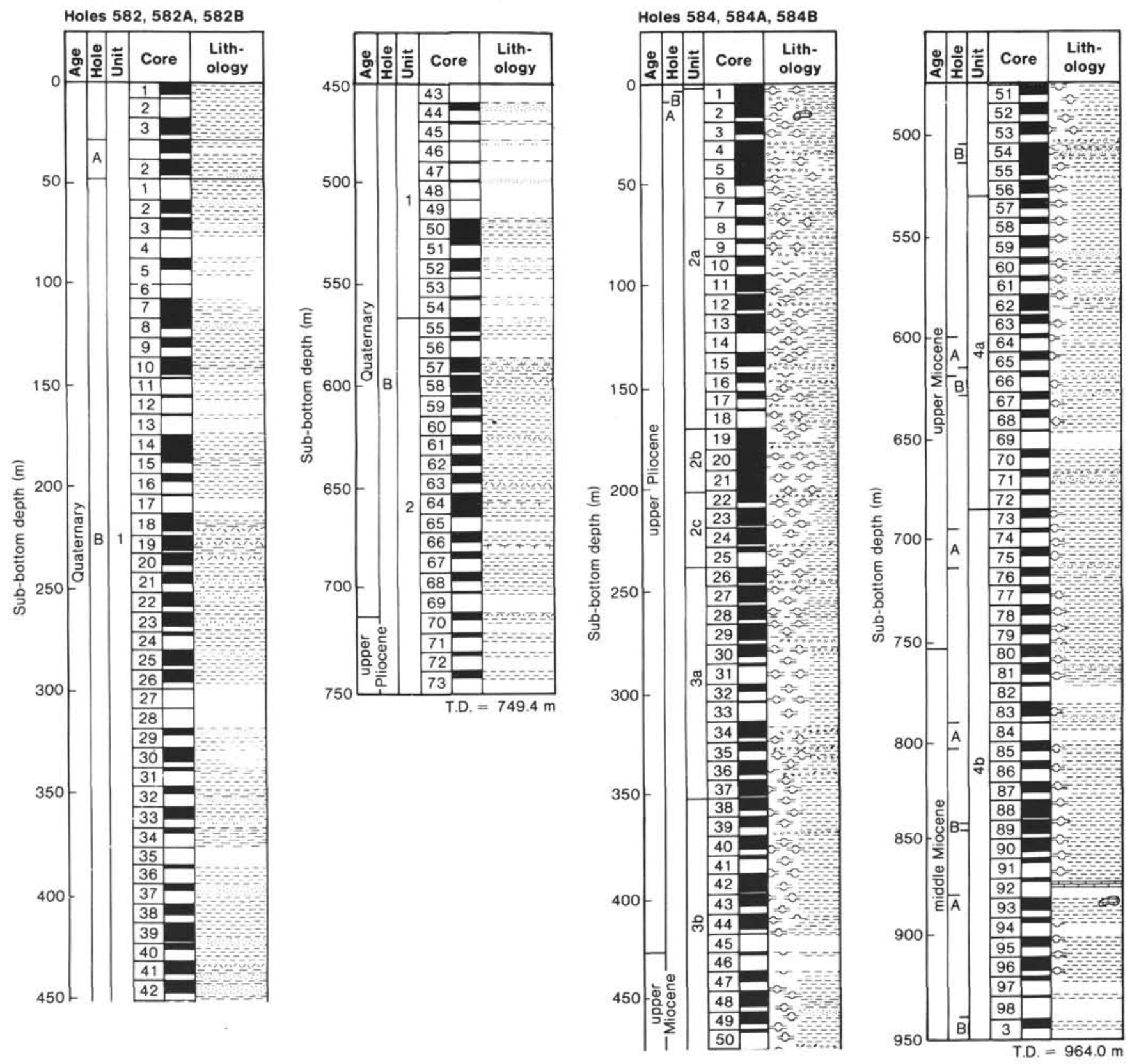

Figure 2. Lithology columns, Sites 582 and 584. For key to lithologic symbols, see Explanatory Notes chapter (this volume). T. D. = total depth.

Biogenic silica in the form of diatoms, sponge spicules, radiolarians, and silicoflagellates is scarce at Site 582 , as is calcium carbonate in the form of foraminifers and calcareous nannofossils.

\section{SITE 584 RESULTS FOR INTERSTITIAL WATER AND SEDIMENT CHEMISTRY AND MINERALOGY}

\section{Pore-Water Chemistry}

From 0 to $260 \mathrm{~m}$ sub-bottom depth, the $\mathrm{pH}$ increases slightly, from 7.27 to 7.80 , but is fairly constant below $260 \mathrm{~m}$ (Table 1). $\mathrm{Cl}$ does not differ significantly from seawater concentrations. The alkalinity varies between 4 and $23 \mathrm{meq} / 1$ (Fig. 6A), reaching a maximum value at
$300 \mathrm{~m}$ sub-bottom depth (site chapter, Site 584, this volume).

The $\mathrm{SO}_{4}$ concentration decreases gradually to 4 mmoles/l at a depth of $400 \mathrm{~m}$ (Fig. 6B). The Mg concentration is relatively high and constant at more than $50 \mathrm{mmoles} / 1$ in the upper $150 \mathrm{~m}$ of sediment, but then shows a slight decrease to about $48 \mathrm{mmoles} / 1$ by $250 \mathrm{~m}$ and a steady decrease to $25 \mathrm{mmoles} / \mathrm{l}$ at $594 \mathrm{~m}$ sub-bottom (Fig. 6B).

Dissolved Ca increases slightly from 10 to 12 mmoles/ 1 in the upper $100 \mathrm{~m}$ of sediments, but decreases to 7 mmoles/1 downhole to a depth of $300 \mathrm{~m}$ and remains relatively constant at $8 \mathrm{mmoles} / \mathrm{l}$ from 450 to $594 \mathrm{~m}$ (Fig. 6C). The dissolved $\mathrm{K}$ decreases from 13 to 10 mmoles/1 with a nearly constant gradient (Fig. 6C). 
Table 1. Interstitial water data, Leg 87.

\begin{tabular}{|c|c|c|c|c|c|c|c|c|c|c|c|c|c|}
\hline $\begin{array}{c}\text { Core-Section } \\
\text { (interval in cm) }\end{array}$ & $\begin{array}{l}\text { Sub-bottom } \\
\text { depth } \\
\text { (m) }\end{array}$ & $\mathrm{pH}$ & $\begin{array}{l}\text { Salinity } \\
\left(\%_{0}\right)\end{array}$ & $\begin{array}{c}\text { Chlorinity } \\
(\% \% 0)\end{array}$ & $\begin{array}{l}\text { Alkalinity } \\
\text { (meq/l) }\end{array}$ & $\mathrm{Mg}$ & $\mathrm{Ca}$ & $\mathrm{Sr}$ & $\mathrm{Na}$ & $\mathrm{K}$ & $\mathbf{L i}$ & $\mathrm{SO}_{4}$ & Silica \\
\hline \multicolumn{14}{|l|}{ Hole 582} \\
\hline $1-3,143-150$ & 4.5 & 7.79 & 33.80 & 19.78 & 21.12 & 48.03 & 6.92 & 0.07 & 481.12 & 13.36 & 0.01 & 12.73 & 0.63 \\
\hline $3-5,120-130$ & 26.9 & 7.19 & 33.00 & 19.99 & 16.26 & 42.91 & 5.65 & 0.07 & 494.14 & 12.95 & 0.01 & 12.13 & 0.66 \\
\hline \multicolumn{14}{|l|}{ Hole $582 \mathrm{~A}$} \\
\hline $1-5,0-10$ & 35.1 & 7.50 & 33.60 & 19.78 & 19.53 & 42.07 & 4.98 & 0.08 & 481.67 & 12.25 & 0.01 & 5.36 & 0.60 \\
\hline $2-5,0-10$ & 44.8 & 7.71 & 33.80 & 19.07 & 24.64 & 43.20 & 4.75 & 0.08 & 465.53 & 11.78 & 0.01 & 5.41 & 0.60 \\
\hline \multicolumn{14}{|l|}{ Hole 582B } \\
\hline $2-2,140-150$ & 61.2 & 7.81 & 33.80 & 19.58 & 28.33 & 43.21 & 4.46 & 0.08 & 483.69 & 12.69 & 0.01 & 5.62 & 0.55 \\
\hline $14-5,138-150$ & 181.5 & 7.98 & 34.60 & 19.68 & 45.62 & 46.39 & 5.14 & 0.09 & 484.61 & 12.88 & 0.01 & 0.00 & 0.43 \\
\hline $18-5,140-150$ & 217.0 & 7.78 & 34.10 & 19.37 & 36.43 & 45.02 & 7.69 & 0.09 & 477.29 & 12.40 & 0.01 & 6.25 & 0.55 \\
\hline $23-1,140-150$ & 252.2 & 7.86 & 33.60 & 19.34 & 23.48 & 40.56 & 6.39 & 0.08 & 477.38 & 11.91 & 0.01 & 7.18 & 0.54 \\
\hline $30-5,138-150$ & 335.4 & 7.85 & 33.00 & 19.10 & 20.36 & 34.68 & 5.11 & 0.07 & 475.49 & 11.60 & 0.01 & 3.85 & 0.61 \\
\hline $33-4,140-150$ & 362.5 & 7.95 & 32.20 & 18.89 & 20.21 & 36.34 & 5.65 & 0.07 & 369.92 & 11.69 & 0.02 & 6.35 & 0.47 \\
\hline $38-3,140-150$ & 408.3 & 7.76 & 33.80 & 19.10 & 20.08 & 36.55 & 4.81 & 0.07 & 485.02 & 11.15 & 0.01 & 10.10 & 0.60 \\
\hline $50-3,135-150$ & 522.3 & 7.89 & 33.60 & 19.07 & 21.34 & 28.26 & 7.61 & 0.08 & 496.98 & 10.97 & 0.02 & 10.31 & 0.60 \\
\hline $54-2,135-150$ & 559.3 & 7.91 & 33.30 & 19.37 & 25.36 & 28.63 & 5.75 & 0.09 & 517.22 & 12.21 & 0.03 & 13.33 & 0.59 \\
\hline $66-2,135-150$ & 674.8 & 7.64 & 33.00 & 18.04 & 18.00 & 25.17 & 9.23 & 0.11 & 489.76 & 11.81 & 0.04 & 21.86 & 0.68 \\
\hline $61-2,135-150$ & 626.7 & 7.70 & 33.30 & 19.20 & 20.62 & 27.81 & 6.47 & 0.11 & 536.41 & 13.00 & 0.05 & 28.00 & 0.67 \\
\hline \multicolumn{14}{|l|}{ Hole 584} \\
\hline $1-4,140-150$ & 4.0 & 7.27 & 36.30 & 19.14 & 3.72 & 52.64 & 10.67 & 0.08 & 457.77 & 13.18 & 0.02 & 27.07 & 0.85 \\
\hline $2-3 \quad 140-150$ & 14.8 & 7.42 & 35.50 & 18.58 & 3.64 & 51.15 & 10.46 & 0.08 & 445.17 & 13.10 & 0.02 & 26.96 & 0.92 \\
\hline $3-3,140-150$ & 24.5 & 7.63 & 36.60 & 19.31 & 4.97 & 52.06 & 10.97 & 0.08 & 462.93 & 13.59 & 0.02 & 26.55 & 1.13 \\
\hline $5-5,140-150$ & 46.3 & 7.41 & 36.50 & 20.01 & 5.61 & 52.75 & 11.58 & 0.08 & 481.88 & 13.06 & 0.02 & 26.86 & 0.99 \\
\hline $6-2,140-150$ & 51.2 & 7.57 & 35.80 & 19.61 & 5.96 & 52.50 & 11.62 & 0.08 & 473.25 & 13.25 & 0.02 & 27.90 & 0.94 \\
\hline $7-1,140-150$ & 59.3 & 7.38 & 35.50 & 19.34 & 5.85 & 52.18 & 11.58 & 0.08 & 461.89 & 11.89 & 0.02 & 25.05 & 0.52 \\
\hline $9-1,140-150$ & 78.5 & 7.39 & 35.80 & 19.44 & 6.59 & 52.27 & 11.45 & 0.08 & 465.33 & 12.38 & 0.02 & 25.19 & 0.80 \\
\hline $10-3,140-150$ & 91.0 & 7.61 & 35.80 & 19.48 & 7.56 & 51.82 & 11.85 & 0.08 & 466.65 & 12.86 & 0.02 & 24.99 & 0.89 \\
\hline $12-5,140-150$ & 113.0 & 7.51 & 35.50 & 19,41 & 7.60 & 50.89 & 11.27 & 0.08 & 466.23 & 12.76 & 0.02 & 24.19 & 0.93 \\
\hline $16-2,135-150$ & 147.0 & 7.52 & 35.80 & 19.21 & 10.33 & 52.13 & 11.44 & 0.08 & 449.89 & 11.43 & 0.03 & 18.22 & 0.84 \\
\hline $19-6,135-150$ & 182.1 & 7.50 & 34.60 & 19.31 & 11.96 & 50.57 & 9.34 & 0.07 & 456.93 & 11.36 & 0.02 & 15.82 & 1.02 \\
\hline $22-3,135-150$ & 206.6 & 7.58 & 34.40 & 19.44 & 14.53 & 48.97 & 8.47 & 0.08 & 468.62 & 10.85 & 0.03 & 15.82 & 1.05 \\
\hline $27-4,135-150$ & 255.8 & 7.79 & 34.60 & 19.78 & 20.35 & 48.43 & 6.16 & 0.08 & 478.15 & 9.53 & 0.03 & 9.37 & 0.49 \\
\hline $32-2,135-150$ & 300.3 & 7.74 & 33.60 & 19.31 & 23.64 & 42.36 & 5.56 & 0.06 & 486.54 & 10.00 & 0.03 & 12.10 & 1.00 \\
\hline $37-5,135-150$ & 352.6 & 7.70 & 33.00 & 19.17 & 19.93 & 37.18 & 5.64 & 0.07 & 473.05 & 10.83 & 0.05 & 4.50 & 0.99 \\
\hline $42-4,135-150$ & 398.9 & 7.74 & 32.40 & 18.91 & 19.98 & 33.37 & 5.97 & 0.10 & 472.34 & 10.69 & 0.07 & 4.27 & 0.78 \\
\hline $47-3,135-150$ & 445.5 & 7.80 & 33.00 & 19.01 & 21.79 & 29.39 & 7.15 & 0.14 & 474.13 & 10.51 & 0.09 & 0.00 & 0.77 \\
\hline $51-2,135-150$ & 482.3 & 7.63 & 33.00 & 19.31 & 19.67 & 29.51 & 6.64 & 0.09 & 481.69 & 10.16 & 0.08 & 0.00 & 0.77 \\
\hline $57-3,135-150$ & 541.1 & 7.71 & 33.00 & 19.21 & 19.87 & 27.33 & 5.92 & 0.09 & 485.05 & 9.99 & 0.09 & 0.00 & 0.56 \\
\hline $62-1,135-150$ & 590.1 & 7.90 & 33.00 & 19.17 & 18.14 & 23.51 & 6.46 & 0.10 & 488.62 & 10.09 & 0.09 & 0.00 & 0.74 \\
\hline
\end{tabular}

Note: $\mathrm{pH}$, salinity, chlorinity, and alkalinity data are from site chapters for Sites 582 and 584, this volume. Concentrations of elements and silica are in mmoles/l.

Dissolved Sr remains constant in the upper $200 \mathrm{~m}$ of sediments, reaches a minimum concentration at about $300 \mathrm{~m}$, then increases to $594 \mathrm{~m}$ (Fig. 6D).

The dissolved $\mathrm{Li}$ concentration is low and relatively constant at $0.02 \mathrm{mmoles} / \mathrm{l}$ in the upper $300 \mathrm{~m}$ of sediment, but then increases steadily to about 0.08 mmoles/l by $450 \mathrm{~m}$, remaining nearly constant at this concentration to a total depth of 594 m (Fig. 6E).

Although dissolved silica analyses show a scatter around $0.8 \mathrm{mmoles} / \mathrm{l}$, there is an overall decrease with depth (Fig. 6F).

\section{Sediment Chemistry}

Sediments remain low and nearly constant in their $\mathrm{Mg} / \mathrm{Al}$, and $\mathrm{Sr} / \mathrm{Al}$ ratios throughout the entire sediment sequence (Fig. 7E, 7D). $\mathrm{Si} / \mathrm{Al}, \mathrm{Ca} / \mathrm{Al}, \mathrm{Na} / \mathrm{Al}$ and $\mathrm{K} / \mathrm{Al}$ ratios generally decrease with depth (Fig. 7A, 7C, 7E, 7F). $\mathrm{Li} / \mathrm{Al}$ ratios are scattered (Fig. $7 \mathrm{G}$ ), and $\mathrm{Zn} / \mathrm{Al}$ ra- tios increase with depth by nearly a factor of 3 (Fig. 7H). Other elements show no marked depth-related trends.

\section{Sediment Mineralogy}

Smear-slide observations indicate that diatom concentrations are high $(60 \%)$ in the upper $200 \mathrm{~m}$ of the sediments, but decrease gradually to $10 \%$ at total depth (Fig. 8).

Other biogenic silica microfossils (such as sponge spicules, radiolarians, and silicoflagellates) are common at Site 584, but biogenic carbonate is scarce.

Quartz and feldspar concentrations gradually increase with depth to $30 \%$. Also, clay concentrations gradually increase, despite considerable scatter within the data. Clay minerals present include kaolinite, illite, and smectite.

Although pyrite and other opaque minerals are found in all the sections, the pyrite concentration is variable from 1 to $6 \%$. 

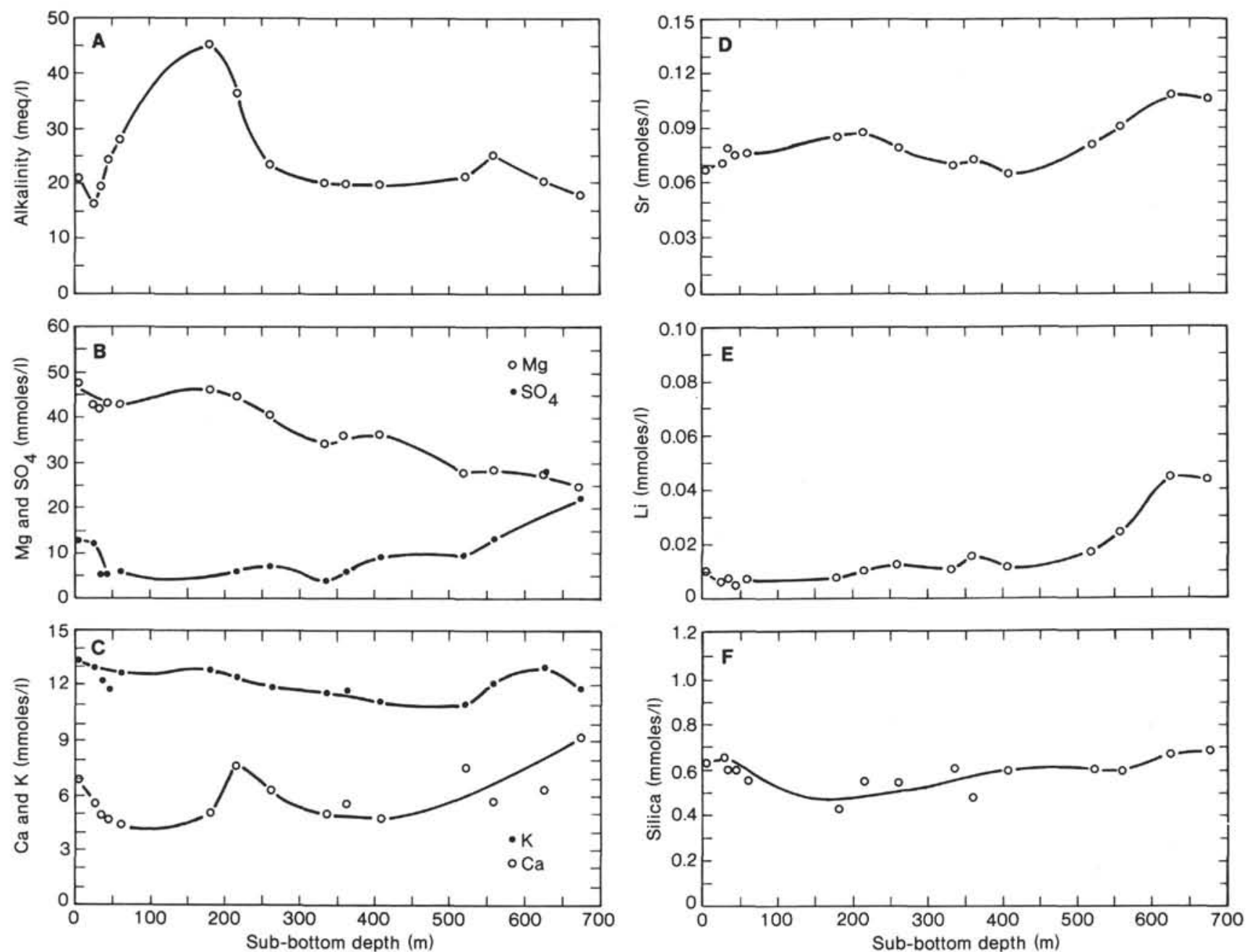

Figure 3. Site 582 interstitial water chemistry. Alkalinity data are from on-board analyses (site chapter, Site 582, this volume). Labels A-F are for text references.

\section{DISCUSSION}

\section{Site $\mathbf{5 8 2}$}

Sulfate reduction is accompanied by the production of secondary pyrite at low temperature, probably owing to reduced sulfur and ferrous iron formation during the production of biogenic methane. The sediments have an organic content between 0.5 and $0.7 \%$ and hydrocarbon gases, mainly methane with very minor $\mathrm{CO}_{2}, \mathrm{C}_{2}$, and $\mathrm{C}_{3}$, and traces of $\mathrm{H}_{2} \mathrm{~S}$ are present (site chapter, Site 582, this volume). Pyrite occurring in cores below the sulfatereducing zone are probably relicts of a time when those strata were within $300 \mathrm{~m}$ of the seafloor.

High alkalinities are accompanied by low concentrations of dissolved sulfate and calcium at Site 582, suggesting precipitation of calcium carbonate in relation to sulfate reduction.

Pore-water concentrations of dissolved $\mathrm{Mg}$ decrease by a factor of 0.85 within the first $4.5 \mathrm{~m}$ below the seawater/sediment interface and then decrease by a factor of 0.5 to a depth of $680 \mathrm{~m}$. Although this trend must be explained in terms of interstitial water interaction with sediments, the $\mathrm{Mg} / \mathrm{Al}$ in sediments is quite constant. Evi- dently, no large quantity of $\mathrm{Mg}$ ions is added to the sediment phase. Probably the sediments of Unit 1 at Site 582 are so young (Quaternary) that the interstitial water has not yet reacted with the sediments.

Dissolved $\mathrm{K}$ does not indicate a sink in the section, also probably a result of incomplete reaction with these relatively young sediments.

\section{Site 584}

Sediments from Sites 438, 439, 440, and 441 of Leg 57 have an average organic carbon content of about $0.8 \%$ (Rullkötter et al., 1980; Sato, 1980). Despite the lack of Leg 87 shipboard analyses of organic carbon, the sediments at Site 584 are estimated to have high organic carbon content. Sulfate reduction is accompanied by the production of pyrite and a large increase in alkalinity, which is responsible for the precipitation of calcium carbonate, as reflected in a minimum dissolution calcium at about $300 \mathrm{~m}$.

There are one or more possible reasons for the increase in dissolved $\mathrm{Sr}$ with depth: (1) carbonate recrystallization processes; (2) alteration of volcanic matter; and (3) ion exchange and reaction between the intersti- 
Table 2. Chemical analyses of sediments, Sites 582 and 584 .

\begin{tabular}{|c|c|c|c|c|c|c|c|c|c|c|c|c|c|c|c|c|}
\hline $\begin{array}{l}\text { Core-Section } \\
\text { (interval in } \mathrm{cm} \text { ) }\end{array}$ & $\mathrm{SiO}_{2}$ & $\mathrm{Al}_{2} \mathrm{O}_{3}$ & $\mathrm{FeO}{ }^{*}$ & $\mathrm{MgO}$ & $\mathrm{CaO}$ & $\mathrm{Na}_{2} \mathrm{O}$ & $\mathrm{K}_{2} \mathrm{O}$ & $\mathrm{TiO}_{2}$ & $\mathrm{P}_{2} \mathrm{O}_{5}$ & $\mathrm{MnO}$ & $\mathrm{Li}$ & Sr & Co & $\mathrm{Ni}$ & $\mathrm{Zn}$ & LOI \\
\hline \multicolumn{17}{|l|}{ Hole 582} \\
\hline $1-3,143-150$ & 59.59 & 16.13 & 6.08 & 2.92 & 1.41 & 3.49 & 2.88 & 0.72 & 0.13 & 0.09 & 77.0 & 149 & 13.01 & 47.29 & 50.33 & 6.56 \\
\hline $3-5,120-130$ & 61.39 & 15.20 & 5.61 & 2.46 & 1.92 & 3.10 & 2.82 & 0.68 & 0.14 & 0.10 & 61.4 & 168 & 16.24 & 44.98 & 66.32 & 6.58 \\
\hline \multicolumn{17}{|l|}{ Hole $582 \mathrm{~A}$} \\
\hline $1-5,0-10$ & 67.61 & 13.77 & 4.51 & 1.97 & 1.95 & 2.75 & 2.51 & 0.56 & 0.10 & 0.09 & 52.7 & 176 & 9.97 & 25.57 & 53.95 & 4.18 \\
\hline $2-5,0-10$ & 59.80 & 16.08 & 6.14 & 2.72 & 1.84 & 2.92 & 2.94 & 0.74 & 0.15 & 0.10 & 68.0 & 162 & 17.29 & 50.89 & 65.48 & 6.57 \\
\hline \multicolumn{17}{|l|}{ Hole 582B } \\
\hline $2-2,140-150$ & 59.05 & 16.09 & 6.32 & 2.72 & 2.23 & 2.89 & 2.91 & 0.74 & 0.15 & 0.11 & 66.0 & 174 & 18.31 & 48.03 & 60.96 & 6.80 \\
\hline $14-5,138-150$ & 57.90 & 16.33 & 6.69 & 3.00 & 2.35 & 2.98 & 2.75 & 0.74 & 0.18 & 0.10 & 74.9 & 190 & 21.45 & 51.89 & 83.99 & 6.98 \\
\hline $18-5,140-150$ & 58.85 & 15.81 & 6.20 & 2.66 & 2.52 & 2.99 & 2.62 & 0.71 & 0.17 & 0.10 & 53.7 & 196 & 16.34 & 44.19 & 73.00 & 7.36 \\
\hline $23-1,140-150$ & 60.97 & 16.32 & 5.98 & 2.56 & 1.32 & 2.92 & 2.93 & 0.71 & 0.14 & 0.08 & 61.8 & 153 & 16.50 & 48.26 & 77.46 & 6.05 \\
\hline $30-5,138-150$ & 60.11 & 15.78 & 6.00 & 2.51 & 2.03 & 2.77 & 2.83 & 0.72 & 0.15 & 0.10 & 60.4 & 165 & 16.08 & 52.33 & 73.93 & 7.01 \\
\hline $33-4,140-150$ & 65.95 & 14.35 & 4.81 & 2.03 & 2.30 & 3.02 & 2.34 & 0.57 & 0.11 & 0.08 & 41.0 & 191 & 11.48 & 45.16 & 57.03 & 4.45 \\
\hline $50-3,135-150$ & 62.28 & 16.10 & 5.94 & 2.62 & 1.21 & 2.85 & 2.90 & 0.76 & 0.15 & 0.09 & 58.3 & 147 & 17.34 & 53.20 & 121.78 & 5.10 \\
\hline $54-2,135-150$ & 61.18 & 16.33 & 7.23 & 2.94 & 0.98 & 2.85 & 2.97 & 0.74 & 0.12 & 0.10 & 61.5 & 140 & 19.38 & 48.77 & 102.22 & 4.55 \\
\hline $66-2,135-150$ & 59.57 & 16.84 & 6.46 & 2.84 & 1.77 & 2.50 & 2.99 & 0.76 & 0.11 & 0.10 & 71.0 & 156 & 18.37 & 56.42 & 114.62 & 6.06 \\
\hline \multicolumn{17}{|l|}{ Hole 584} \\
\hline $1-4,140-150$ & 66.29 & 8.57 & 3.05 & 1.40 & 3.93 & 2.96 & 1.59 & 0.32 & 0.06 & 0.04 & 48.6 & 182 & 5.96 & 26.30 & 19.58 & 11.79 \\
\hline $2-3,140-150$ & 70.42 & 7.76 & 2.83 & 0.99 & 2.39 & 2.93 & 1.50 & 0.26 & 0.03 & 0.04 & 45.2 & 133 & 3.73 & 26.83 & 18.40 & 10.86 \\
\hline $3-3,140-150$ & 71.78 & 7.78 & 2.79 & 1.26 & 0.99 & 3.03 & 1.31 & 0.29 & 0.02 & 0.04 & 34.0 & 100 & 4.57 & 24.33 & 21.04 & 10.72 \\
\hline $5-5,140-150$ & 68.71 & 6.99 & 2.41 & 1.11 & 0.64 & 2.86 & 1.22 & 0.24 & 0.01 & 0.03 & 34.4 & 85 & 0.72 & 20.88 & 15.46 & 15.77 \\
\hline $6-2,140-150$ & 66.25 & 10.54 & 4.41 & 1.17 & 2.57 & 3.17 & 1.11 & 0.36 & 0.04 & 0.06 & 29.8 & 124 & 5.83 & 19.43 & 26.34 & 10.31 \\
\hline $7-1,140-150$ & 71.21 & 7.83 & 2.56 & 1.20 & 0.70 & 3.28 & 1.55 & 0.27 & 0.02 & 0.04 & 44.2 & 86 & 0.86 & 23.25 & 19.69 & 11.34 \\
\hline $9-1,140-150$ & 72.44 & 7.05 & 2.42 & 1.21 & 0.63 & 3.04 & 1.31 & 0.26 & 0.01 & 0.03 & 44.0 & 86 & 2.68 & 21.50 & 15.94 & 11.61 \\
\hline $10-3,140-150$ & 68.81 & 9.42 & 3.49 & 1.55 & 1.20 & 3.04 & 1.58 & 0.38 & 0.04 & 0.04 & 40.7 & 115 & 7.16 & 30.58 & 26.24 & 10.46 \\
\hline $12-5,140-150$ & 68.74 & 8.69 & 3.20 & 1.51 & 0.99 & 2.86 & 1.62 & 0.34 & 0.04 & 0.04 & 43.2 & 100 & 8.50 & 36.88 & 32.47 & 11.97 \\
\hline $16-2,135-150$ & 71.89 & 6.83 & 2.65 & 1.13 & 0.73 & 2.94 & 1.58 & 0.23 & 0.02 & 0.03 & 47.5 & 78 & 5.65 & 25.38 & 24.91 & 11.98 \\
\hline $19-6,135-150$ & 71.99 & 6.24 & 2.25 & 1.10 & 1.50 & 2.66 & 1.37 & 0.21 & 0.02 & 0.03 & 53.3 & 102 & 6.15 & 31.11 & 17.05 & 12.63 \\
\hline $22-3,135-150$ & 71.81 & 6.40 & 2.26 & 1.10 & 1.02 & 2.69 & 1.40 & 0.22 & 0.01 & 0.03 & 52.8 & 91 & 6.26 & 27.38 & 21.08 & 13.07 \\
\hline $27-4,135-150$ & 74.62 & 6.57 & 2.44 & 1.05 & 0.72 & 2.50 & 1.28 & 0.22 & 0.02 & 0.03 & 40.4 & 82 & 4.70 & 26.38 & 15.98 & 10.55 \\
\hline $32-2,135-150$ & 69.79 & 9.79 & 3.68 & 1.65 & 0.78 & 2.86 & 1.49 & 0.39 & 0.04 & 0.05 & 37.2 & 106 & 6.30 & 30.46 & 33.03 & 9.48 \\
\hline $37-5,135-150$ & 67.10 & 11.30 & 4.24 & 1.92 & 0.96 & 2.97 & 1.83 & 0.45 & 0.05 & 0.05 & 43.2 & 121 & 9.55 & 51.62 & 53.77 & 9.11 \\
\hline $42-4,135-150$ & 66.32 & 11.77 & 4.60 & 1.97 & 0.82 & 3.01 & 1.94 & 0.49 & 0.06 & 0.16 & 49.4 & 122 & 9.30 & 49.62 & 58.60 & 8.85 \\
\hline $47-3,135-150$ & 69.17 & 10.52 & 4.05 & 1.75 & 0.53 & 2.80 & 1.80 & 0.42 & 0.04 & 0.05 & 52.8 & 102 & 9.47 & 33.87 & 45.62 & 8.88 \\
\hline $51-2,135-150$ & 66.78 & 12.24 & 4.74 & 2.30 & 0.89 & 2.86 & 1.92 & 0.58 & 0.07 & 0.06 & 47.2 & 129 & 11.55 & 41.00 & 71.43 & 7.56 \\
\hline $57-3,135-150$ & 65.81 & 12.80 & 5.31 & 2.51 & 1.14 & 2.78 & 1.94 & 0.62 & 0.07 & 0.06 & 55.2 & 141 & 8.54 & 33.57 & 73.25 & 6.96 \\
\hline $62-1,135-150$ & 63.51 & 14.37 & 6.05 & 2.79 & 1.46 & 3.06 & 2.13 & 0.72 & 0.11 & 0.10 & 54.1 & 160 & 19.02 & 75.19 & 85.85 & 5.69 \\
\hline
\end{tabular}

Note: $\mathrm{SiO}_{2}, \mathrm{Al}_{2} \mathrm{O}_{3}, \mathrm{FeO} *, \mathrm{MgO}, \mathrm{CaO}, \mathrm{Na}_{2} \mathrm{O}, \mathrm{K}_{2} \mathrm{O}, \mathrm{TiO}_{2}$, and $\mathrm{P}_{2} \mathrm{O}_{5}$ concentrations are expressed in \%; other concentrations are in ppm. * indicates that total iron is expressed as $\mathrm{FeO}^{*}$. $\mathrm{LOI}$ is loss on ignition (i.e., loss on heating to $1000^{\circ} \mathrm{C}$ ).

tial water and clay minerals. Although it is difficult to speculate about the processes because of the absence of $\mathrm{Sr}$ isotope data at this time, we postulate that the $\mathrm{Sr}$ source is associated with the recrystallization reactions. The reason is that the dissolved $\mathrm{Ca}$ profile, like the $\mathrm{Sr}$ profile, shows a minimum at $300 \mathrm{~m}$ sub-bottom. In contrast, the alkalinity profile shows a maximum at the same depth.

Dissolved $\mathrm{Mg}$ appears to be consumed throughout the sediment column during diagenesis. Identification of newly formed silicate minerals is hampered, however, because of dilution by similar detrital minerals. At Site 584 detrital materials are relatively fresh and authigenic calcitic and dolomitic concretions occur (Matsumoto et al., this volume).

Usually decreases in dissolved $\mathrm{Mg}$ are associated with the alteration of volcanic matter in pelagic sediments (Perry et al., 1976). In a continental margin setting, however, where rapid accumulation rates and high organic carbon contents lead to very high alkalinity values, carbonate precipitation and dolomitization may be the cause of the observed magnesium depletions. But $\mathrm{Mg}$-rich and
Fe-rich carbonate concretions are found in discreet depth intervals. Another possibility is that dissolved $\mathrm{Mg}$ depletion results from ion exchange and reaction between interstitial water and clay minerals.

The distribution of pore-water $\mathrm{Na}$ values is reflected in the sediment chemistry. Dissolved $\mathrm{Na}$ concentrations increase with depth, whereas the $\mathrm{Na} / \mathrm{Al}$ ratio decreases in the sediment column. Despite no clear evidence, the formation of secondary minerals probably controls this trend.

\section{RELATIONS BETWEEN INTERSTITIAL WATER AND SEDIMENTS}

\section{Dissolved Silica Content}

Dissolved silica analyses for Site 584 are scattered around $0.8 \mathrm{mmoles} / \mathrm{l}$, a typical value for sediment containing both clay minerals and biogenic silica. Diatom frustules occur throughout, even at $590 \mathrm{~m}$ (the deepest interstitial water sample). We found no secondary silica minerals at this site, perhaps because of the low geothermal gradient. 

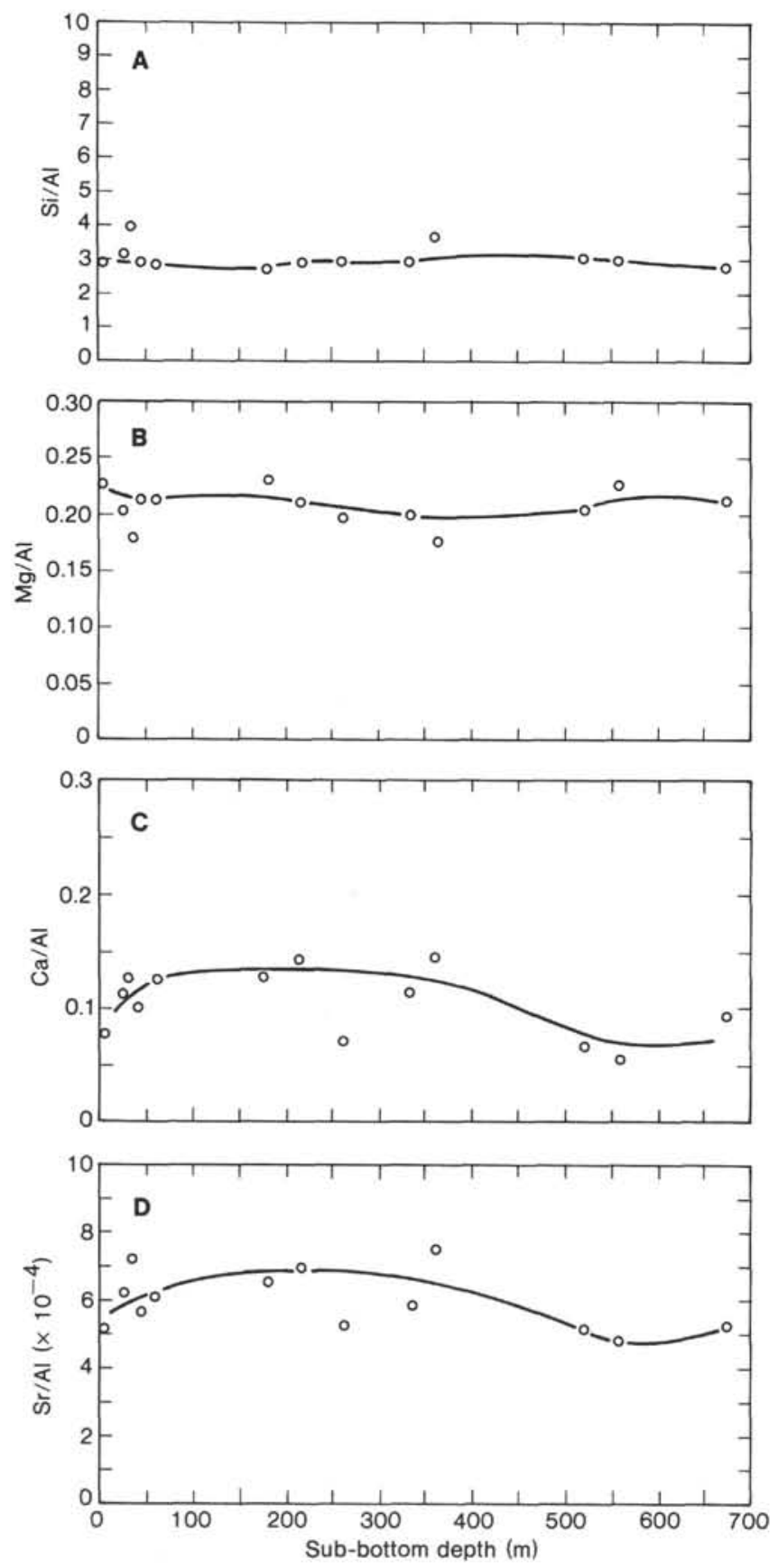

Figure 4. Site 582 sediment chemistry. Labels A-H are for text references.

Dissolved silica concentration increases slightly with depth at Site 582. Its average is $0.6 \mathrm{mmoles} / \mathrm{l}$, less than that at Site 584. The sediments at Site 582 mainly consist of clay minerals, quartz, and feldspar and contain little or no biogenic opal. In general, quartz and feldspar resist diagenesis, and the dissolution of opaline silica exceeds the dissolution of clay minerals. Probably the difference in mineral composition at these sites arises from initial disparate silica concentrations between each location.

As previously stated, the distribution of $\mathrm{SiO}_{2}$ in the interstitial water is reflected in the sediment chemistry of the two sites. Higher $\mathrm{Si} / \mathrm{Al}$ values in the sediment are
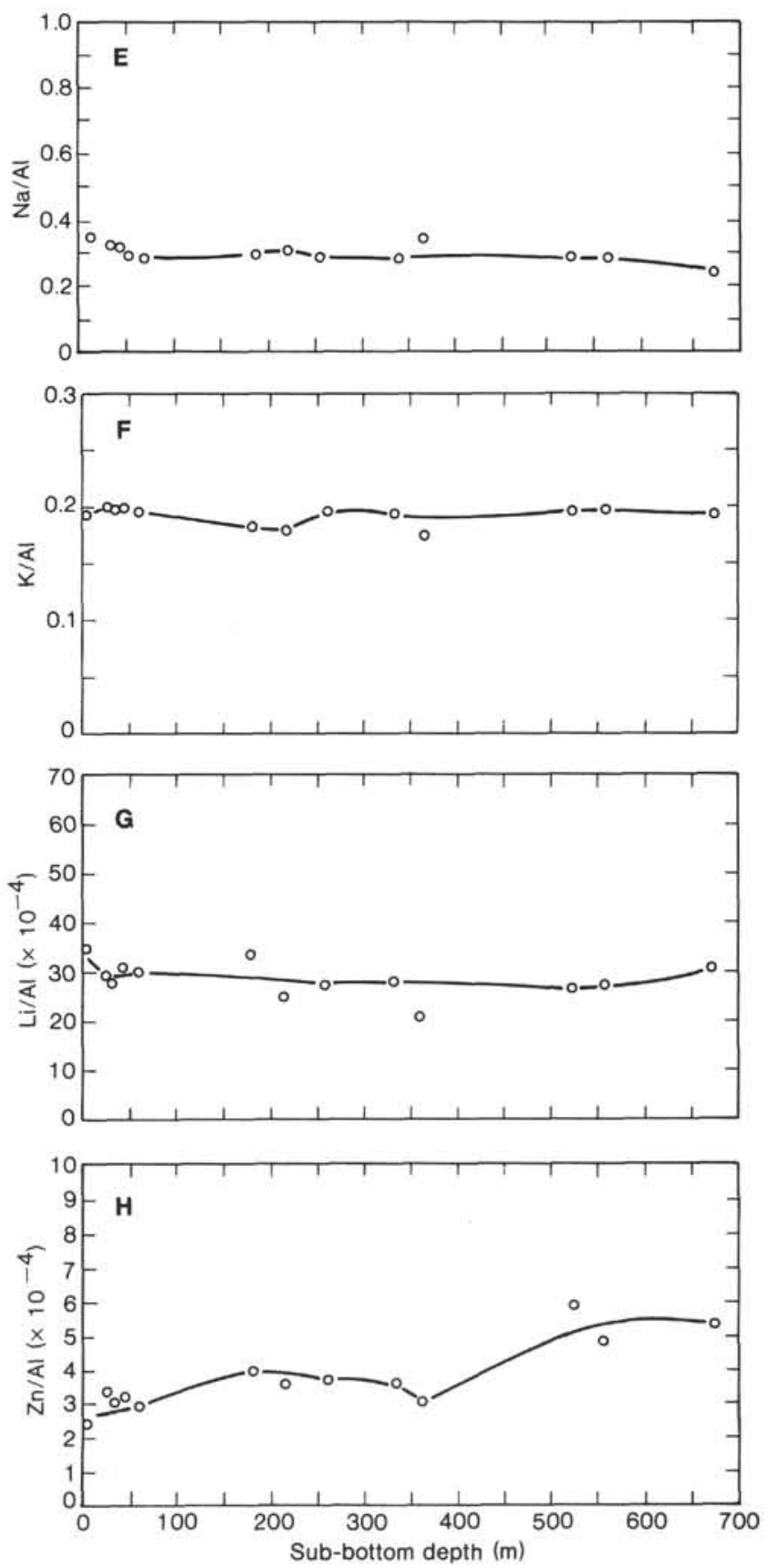

roughly correlated with higher values of interstitial water $\mathrm{SiO}_{2}$ at Site 584 (Fig. 9), suggesting that the presence of biogenic opal is probably responsible for higher dissolved silica in interstitial water.

\section{Dissolved Lithium Content}

The profiles of dissolved $\mathrm{Li}$ at Sites 582 and 584 are of interest; they show 3 zones (compare Fig. 3E, 6E, and 10). The Li concentrations increase gradually in Zone 1, then more sharply (by a factor of 5) in Zone 2. In Zone 3 the dissolved $\mathrm{Li}$ concentrations are high and remain fairly constant. The distribution of interstitial water $\mathrm{Li}$ values are not reflected in sediment chemistry (Figs. 5, 


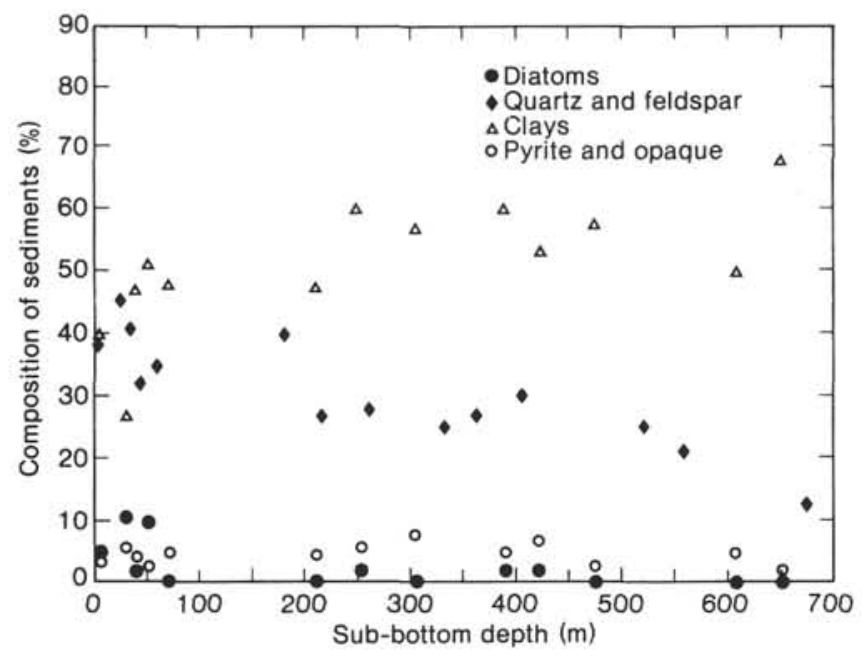

Figure 5. Site 582 sediment composition with depth.

and 7). Although increases in dissolved Li concentrations may be related to its release from clay minerals, there is another related possibility. Dewatering structures are observed below Unit 4 at Site 584 (site chapter Site 584 , this volume). At Site 582 dewatering veinlets are not common, but faults and fissures exist and their permeability is much lower than that of normal sediments. The high and constant $\mathrm{Li}$ concentrations may be related to advection that results from dewatering processes and fluid transport (Kinoshita et al., this volume).

\section{SUMMARY AND CONCLUSIONS}

Both the Nankai Trough and the Japan Trench were explored during Leg 87 . Site 582 is on the floor of the Nankai Trough and Site 584 is situated on the deep-sea terrace of the Japan Trench. Our investigation of the chemistry of the interstitial water and sediments, as well as the sediment mineralogy, reveals that:

1. Sulfate reduction is accompanied by the production of secondary pyrite, which is rich in the sedimentary column at both sites.

2. Dissolved Ca concentrations are relatively low and change slightly at both sites, probably because of the formation of carbonate with high alkalinity.

3. Concentrations of dissolved $\mathrm{Mg}$ decrease with depth at Site 584. Dissolved $\mathrm{Mg}$ depletion probably results from the formation of $\mathrm{Mg}$-rich carbonate and/or ion exchange and reaction between interstitial water and clay minerals.
4. Higher $\mathrm{Si} / \mathrm{Al}$ values caused by biogenic opal in the sediments correlate roughly with higher values of interstitial water $\mathrm{SiO}_{2}$.

5. Increases in dissolved $\mathrm{Li}$ concentrations may be related to its release from clay minerals and/or to advection that results from dewatering processes and/or fluid transport.

\section{ACKNOWLEDGMENTS}

We wish to thank Drs. M. Nohara and S. Wakamiya for reviewing the manuscript. The ion-coupled plasma measurements were carried out in the laboratory of associate Professor N. Notsu at Tsukuba University. All figures showing concentrations with depth were plotted by the GEOCAPS program (Yoshii and Sato, 1983) in the laboratory of Dr. Yoshii at the Geological Survey of Japan. We are also grateful to them.

\section{REFERENCES}

Karig, D. E., Kagami, H., and DSDP Leg 87 Scientific Party, 1983. Varied responses to subduction in Nankai Trough and Japan Trench fore arcs. Nature, 304(5922):148-151.

Lawrence, J. R., Gieskes, J. M., and Broecker, W. S., 1975. Oxygen isotope and cation composition of DSDP pore waters and the alteration of layer 2 basalts. Earth Planet. Sci. Lett., 27:1-10.

Leg 87 Scientific Party, 1983. Leg 87 drills off Honshu and SW Japan. Geotimes, 28(1):15-18.

Matsuii, Y., 1963. Analytical and geochemical investigation of volcanic rocks. Pap. Inst. Therm. Spring Res. Okayama Univ., 32:1-85 (in Japanese).

Moore, G. W., Gieskes, J. M., 1980. Interaction between sediment and interstitial water near the Japan trench, Leg 57, Deep Sea Drilling Project. In Scientific Party, Init. Repts. DSDP, 56, 57, Pt. 2: Washington (U.S. Govt. Printing Office), 1269-1276.

Notsu, K., 1980. Analytical method of ICP for geochemistry. Kagaku no Ryoiki, 127:217-230 (in Japanese).

Perry, E. A., Gieskes, J. M., and Lawrence, J. R., 1976. Mg, Ca, and ${ }^{18} \mathrm{O} /{ }^{16} \mathrm{O}$ exchange in the sediment-pore water system, Hole 149 , DSDP. Geochim. Cosmochim. Acta, 40:413-423.

Rullkötter, J., Cornford, C., Flekken, P., and Welte, D. H., 1980. Organic geochemistry of sediments cored during Deep Sea Drilling Project Legs 56 and 57, Japan Trench: organic petrography and extractable hydrocarbons. In Scientific Party, Init. Repts. DSDP, 56, 57, Pt. 2: Washington (U.S. Govt. Printing Office), 1291-1304.

Sato, S., 1980. Diagenetic alteration of organic matter in Leg 57 sediments, Deep Sea Drilling Project. In Scientific Party, Init. Repts. $D S D P, 56,57$, Pt. 2: Washington (U.S. Govt. Printing Office) 1305-1312.

Yoshii, M., and Sato, T., 1983. An outline of GEOCAPS, a geochemical data analysis program system in Basic. Jpn. Soc. Geol. Data Processing, 8:21-40. (in Japanese with English abstract)

Date of Initial Receipt: 6 July 1984

Date of Acceptance: 30 November 1984 

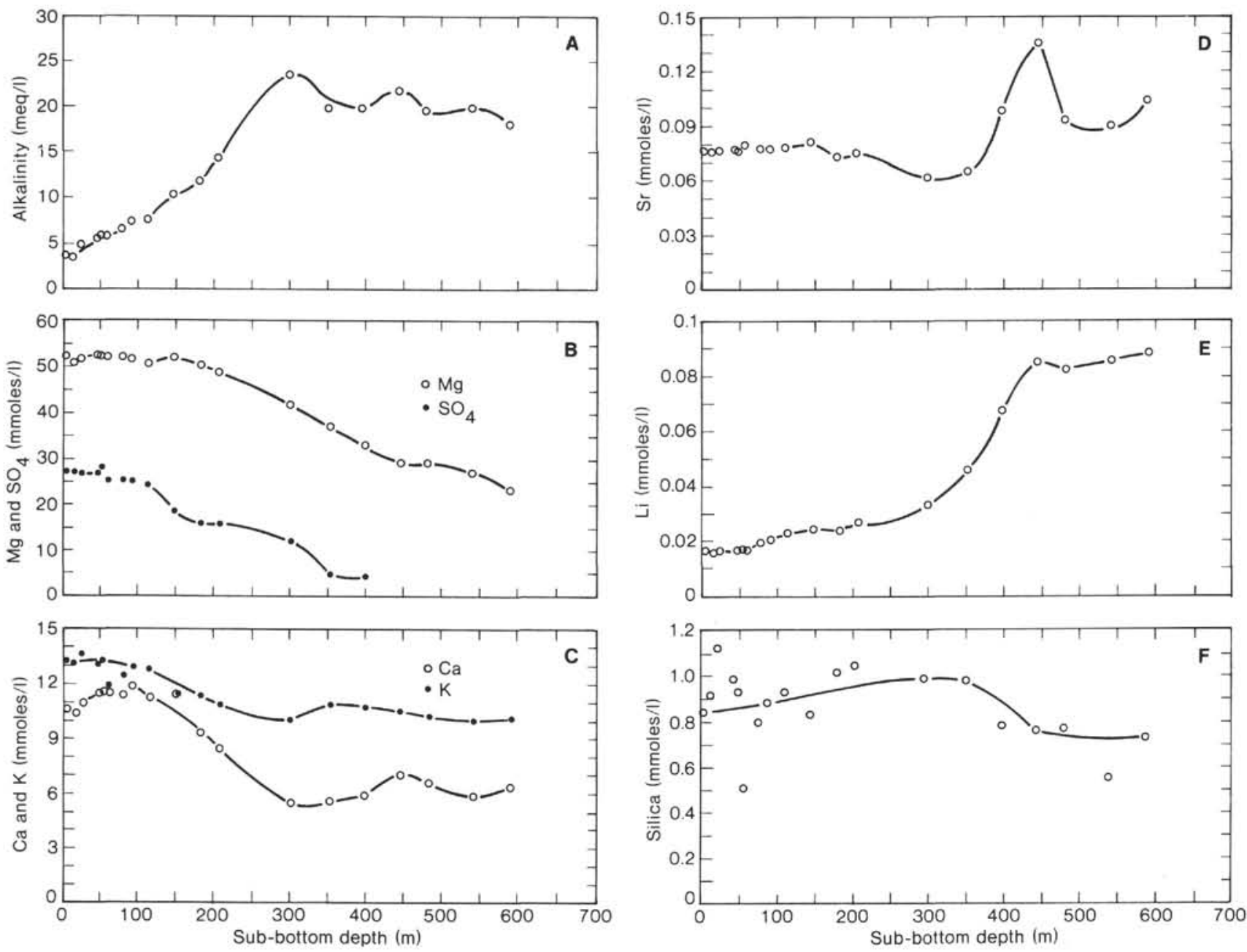

Figure 6. Site 584 interstitial water chemistry. Alkalinity data are from on-board analyses (site chapters, Sites 582 and 584 , this volume). Labels A-F are for text references. 

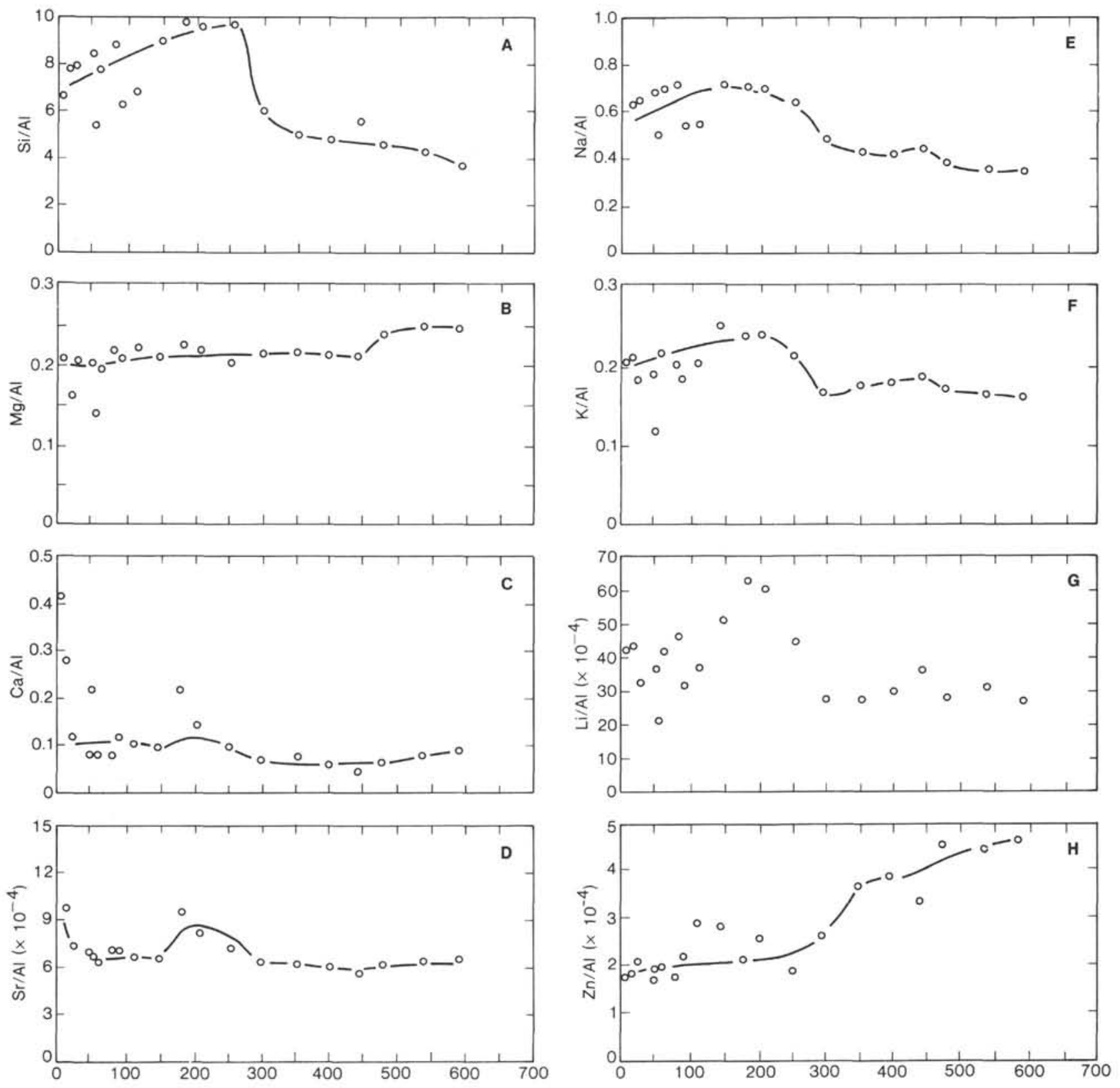

Figure 7. Site 584 sediment chemistry. Labels A-H are for text references. 


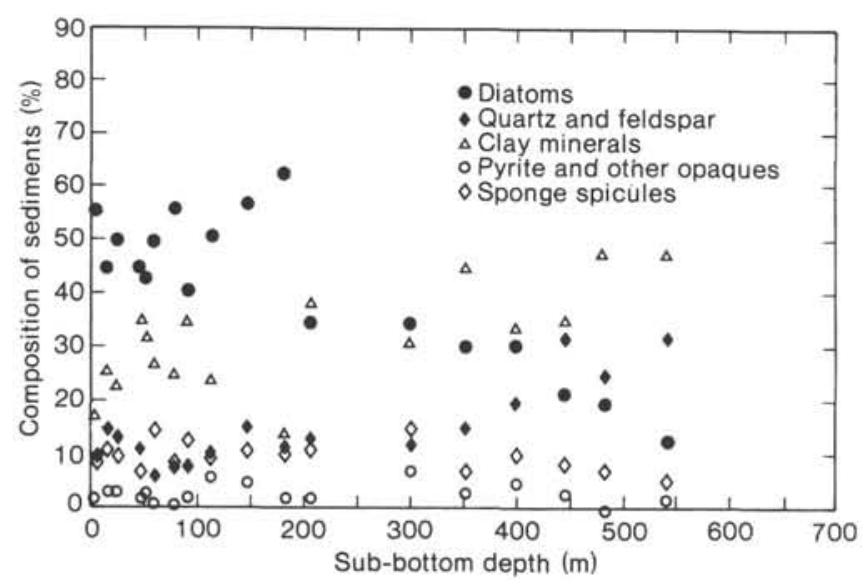

Figure 8. Site 584 sediment composition with depth.

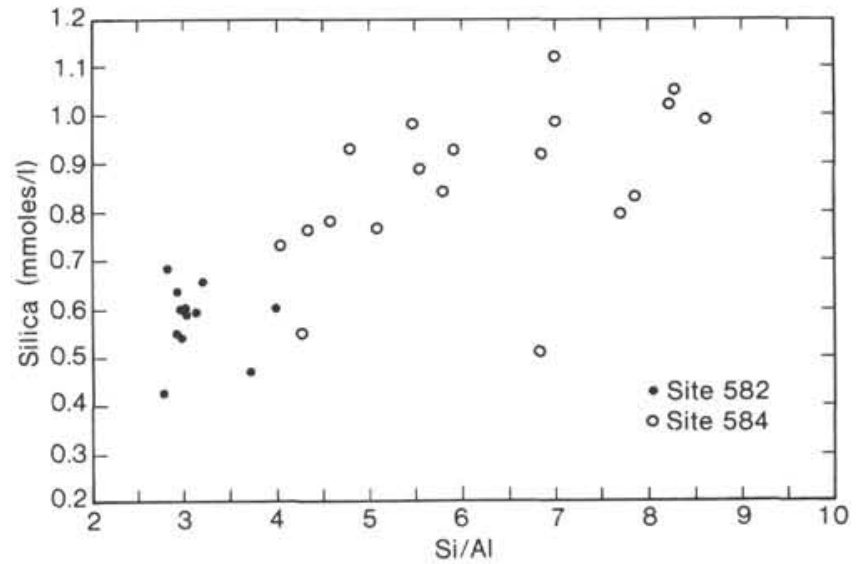

Figure 9. Relation between silica in interstitial water and $\mathrm{Si} / \mathrm{Al}$ ratio in sediments.

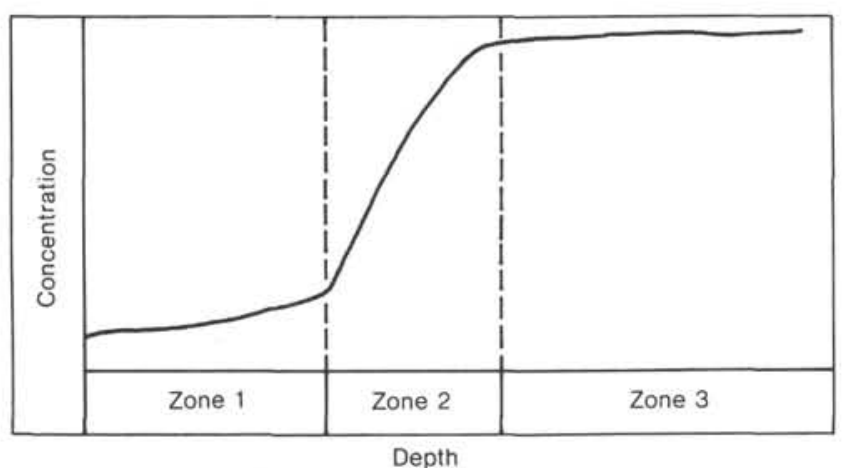

Figure 10. Schematic diagram of dissolved Li concentrations with depth. 